\title{
Влияние сидеральных культур на плодородие почвы, урожайность и качество картофеля
}

\author{
Influence of siderate crops on soil fertility, yield and quality of potato
}

Остонакулов Т.Э., Усмонов Н.Н.

\section{Аннотация}

Цель исследований - оценка влияния различных сидеральных культур на рост, развитие, формирование урожая, урожайность и семенные качества сортов картофеля, а также на плодородие почвы, и на их основе подбор лучших сидеральных культур, позволяющих получить устойчивый высокий здоровый урожай семенного картофеля. В 2016-2019 годах проведены исследования на староорошаемых среднесуглинистых типичных сероземных почвах с залеганием грунтовых вод 5-7 м. Почвы характеризовались благоприятными агрофизическими свойствами и низким содержанием гумуса, нитратного азота, подвижного фосфора, средним содержанием обменного калия. Изучали раннеспелые сорта Кувонч-1656м, среднеранние - Бахро-30, Sante и Kondor после следующих летних и озимых сидеральных культур - рапс, масличная редька, ячмень, горох, горчица сизая и горох+масличная редька. Контроль - зяблевая вспашка. Наибольшая урожайность биомассы (29,9-34,5 т/га) отмечена у летних и озимых сидератных культур - гороха, рапса, масличная редька и гороха+масличной редьки. После этих сидератов доля макроагрегатов (>0,25мм) в слое 0-30 см была на 1,6-8,6 (летних), 5,8-9,6\% больше (озимых), объемная масса на 0,040,07 г/ см $^{3}$ ниже в сравнении с контролем. После лучших сидератов (горох, рапс и горох+масличная редька) содержание гумуса в пахотном слое повышается на 0,01-0,02\%, нитратного азота 7,40-10,05 мг/кг, подвижного фосфора 14,4-16,3 мг/кг, обменного калия 10,36-21,10 мг/кг по сравнению с контролем. При посадке картофеля после выделенных сидератов полевая всхожесть семенных клубней составила по сортам 99,6-99,9\%, всходы появлялись раньше на 2-6 дней по сравнению с контролем, а вегетационный период удлиняли на 4-8 дней, площадь листовой поверхности была на 20,6-21,7 тыс. м² больше, урожай клубней с куста на 206,0-223,7 г больше, чем контроля. При этом был получен самый высокий урожай товарных (30,0-35,0 т/га) и семенных клубней $(21,5-25,4$ т/га) с коэффициентом размножения $(6,5-7,7)$. При посадке семенных клубней изученных copтов картофеля, выращенных после лучших сидератов (горох и горох+масличная редька), установлено, что зараженность растений вирусами снижалась на 9,7-10,2\% (в явной форме), а в латентной форме на 21,9-22,2\%. Доля вырожденных клубней уменьшается на 3,0-3,4\% и способствует получению здорового урожая семенного картофеля.

Ключевые слова: сидеральные культуры, зеленое удобрение, биомасса, продуктивность, выход товарного и семенного урожая, коэффициент размножения, семенные качества.

Для цитирования: Остонакулов Т.Э., Усмонов Н.Н. Влияние сидеральных культур на плодородие почвы, урожайность и качество картофеля // Картофель и овощи. 2020. №5. С. 31-34. https://doi. org/10.25630/PAV.2020.74.31.006

\section{Ostonakulov T.E., Usmonov N.N.}

\section{Abstract}

The purpose of the research is to study the influence of various siderate crops on the growth, development, yield formation, yield and seed quality of potato varieties, as well as soil fertility elements, and on their basis the selection of the best siderate and varieties, allowing to obtain a stable high healthy seed potato. In 2016-2019, studies were carried out on old-irrigated medium loamy typical gray-earth soils with a groundwater table of 5-7 $\mathrm{m}$. The soils were characterized by favorable agrophysical properties and a low content of humus, nitrate nitrogen, mobile phosphorus, and an average content of exchange potassium. We studied early ripe varieties Kuvonch-1656m, midearly varieties Bahro-30, Sante and Kondor for the following summer and winter siderates: rapeseed, oil radish, barley, peas, mustard, and peas+oil radish. Winter plowing served as control. The highest biomass productivity (29.9-34.5 t/ha) was observed in summer and winter siderate crops - peas, rapeseed, oilseed radish and pea+oil radish. With these siderates, the proportion of macroaggregates $(>0.25 \mathrm{~mm})$ in the $0-30 \mathrm{~cm}$ layer was $1.6-8.6$ (summer), 5.8$9.6 \%$ more (winter), and the bulk mass was $0.04-0.07 \mathrm{~g} / \mathrm{cm}^{3}$ lower in comparison with the control. After the best siderates (peas, rapeseed and peas + oil radish), the humus content in the arable layer increases by $0.01-0.02 \%$, nitrate-nitrogen $7.40-10.05 \mathrm{mg} / \mathrm{kg}$, mobile phosphorus $14.4-16.3 \mathrm{mg} / \mathrm{kg}$, potassium exchange 10.36$21.10 \mathrm{mg} / \mathrm{kg}$ compared with the control. Potato planting after selected siderate crops the germination of seed tubers was 99.6$99.9 \%$ by variety, seedlings were accelerated by 2-6 days, and the growing season was extended by 4-8 days, the leaf surface area was 20.6-21.7 thousand $\mathrm{m}^{2}$ more, the harvest of tubers from the bush is 206.0-223.7 g more than the control. At the same time, the highest yield of marketable (30.0-35.0 t/ha) and seed tubers (21.5-25.4t/ha) with a reproduction ratio (6.5-7.7) was obtained. When planting seed tubers of the studied potato varieties grown after the best siderates (peas and peas + oil radish), it was found that the infection of plants with viruses decreased by $9.7-10.2 \%$ (in the explicit form), and in a latent form by $21.9-22.2 \%$. The proportion of degenerated tubers decreases by $3.0-3.4 \%$ and contributes to a healthy harvest of seed potatoes.

Key words: siderate crops, green fertilizers, biomass, productivity, yield of commodity and seed crops, reproduction coefficient, seed quality.

For citing: Ostonakulov T.E., Usmonov N.N. Influence of siderate crops on soil fertility, yield and quality of potato. Potato and vegetables. 2020. No5. Pp. 31-34. https://doi.org/10.25630/PAV.2020.74.31.006 (In Russ.). звестно, что в сохранении и повышении плодородия почвы важную роль играет внесение сидератов. Оно положительно влияет на величину и качество урожая, особенно на снижение зараженности вирусами семенного картофе- ля. На сегодняшний день в литературе представлено влияние сидератных культур на плодородие почвы, рост, развитие, засоренность растений, зараженность болезнями и урожайность хлопчатника, зерновых и других культур [1, 2, 3, 4] и карто- феля [5, 6, 7, 8]. Однако влияние летних и осенних сидеральных культур на плодородие почвы, рост, развитие, формирование урожая, количество и качество урожая сортов картофеля Сантэ, Кондор, Кувонч-1656 м и Бахро-30 в условиях Узбекистана 
изучено не было. Цель исследований - оценка влияния различных сидеральных культур на рост, развитие, формирование урожая, урожайность и семенные качества сортов картофеля, а также на плодородие почвы, и на их основе подбор лучших сидеральных культур, позволяющих получить устойчивый высокий здоровый урожай семенного картофеля.

Условия, материалы и методы исследований

Исследования проведены в условиях староорошаемых типичных сероземных почв фермерского хозяйства «Хисор» Яккабагского района Кашкадарьинской области Республики Узбекистан в 20162019 годах. Гранулометрический состав почвы среднесуглинистый, с залеганием грунтовых вод 5-7 м. Содержание гумуса в пахотном слое (0-30 см) почвы опытного участка - 1,08-1,12\%, объемная масса -

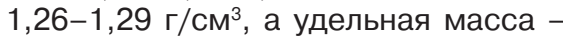

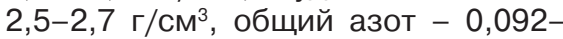
0,096\%, фосфор - 0,148-0,162\%, калий - 2,7-2,8\%, нитратного азота - 5,18-6,56 мг/кг, подвижного фосфора - 18-23 мг/кг и обменного калия - 286-298 мг/кг.

Объект исследования: посадочный материал раннеспелого сорта Кувонч-1656 м (первая репродукция), среднераннего Бахро-30 (селекции Самаркандского с.- х. института), а также среднеранние сорта Sante и Kondor (Нидерланды), а также следующие сидеральные культуры:

І. Летние сидераты (озимая сидерация)

1. Зяблевая вспашка (контроль);

2. Рапс (сорт Немерчанский-2268);

3. Масличная редька (сорт Радуга);

4. Ячмень (сорт Тимур);

5. Горох (сорт Восток-55);

6. Горчица сизая (сорт Юбилейная);

7. Горох+масличная редька.

II. Озимые сидераты (весенняя сидерация)

1. Зяблевая вспашка (контроль);

2. Весновспашка;

3. Рапс (сорт Немерчанский-2268);

4. Масличная редька (сорт Радуга);

5. Ячмень (сорт Тимур);

6. Горох (сорт Восток-55);

7. Горчица сизая (сорт Юбилейная);

8. Горох+масличная редька.

Площадь учетной делянки по сидератам $224 \mathrm{M}^{2}$, по сортам - $14 \mathrm{M}^{2}$, повторность опыта четырехкратная. Посев сидеральных культур проводили в два срока: летом 26-28 июля, осенью 14-19 октября, нормы высева: рапса - 16,0; ячменя - 160; горо- ха - 70; горчицы сизой - 14,0; масличной редьки - 20,0 кг/га, а при совмещенном посеве культур использовали половинную норму для каждой культуры. Удобрений вносили в норме $\mathrm{N}_{30} \mathrm{P}_{100} \mathrm{~K}_{60} \mathrm{Kг/га.} \mathrm{После} \mathrm{посе-}$ ва посевы летних сидератов поливали девять раз в норме 500-600 м³/га, а озимых сидератов - два раза - осенью и весной.

У озимых сидеральных культур за 10-12 дней до посадки картофеля, а у летних сидератов поздней осенью определяли урожайность в период массового цветения или колошения, затем с помощью агрегата КИР. 1,5 измельчали. Растительные остатки дисковали и запахивали на глубину 28-30 см.

Все учеты, анализы, наблюдения и мероприятия в опытах выполняли по общепринятым методикам [9, 10].

\section{Результаты исследований}

Урожайность биомассы у летних сидеральных культур составила 18,7-30,0 т/га. Самой высокой (29,9-30,0 т/га) она была у масличной редьки и смеси горох+масличная редька. У озимых сидератов урожайность биомассы по видам составила 21,9-34,5 т/га. Самой высо- кой (34,5 т/га) она была у масличной редьки, относительно высокий урожай $(31,6$ т/га) был при посеве смеси горох+масличная редька.

При использовании летних сидератов доля макроагрегатов более 0,25 мм была на 1,6-8,6\% больше по сравнению с контролем. Наибольшая $(13,1-17,8 \%)$ доля макроагрегатов (>0,25 мм) отмечена при использовании смеси горох+масличная редька.

у озимых сидеральных культур - горох и горох+масличная редька - доля макроагрегатов (>0,25 мм) в пахотном слое 0-30 см составила $14,6-19,2 \%$, что на $5,8-9,6 \%$ выше контроля.

При использовании летних сидератов объемная масса почвы (030 см) до первого полива вегетирующих растений картофеля была

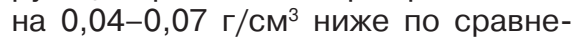
нию с контролем. Наибольшее сни-

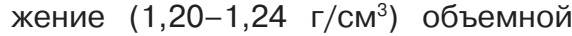
массы почвы отмечено в вариантах горох+масличная редька и горох. При последующих поливах существенное снижение (0,04-0,07 г/ $\mathrm{cm}^{3}$ ) объемной массы почвы было отмечено после сидеральных культур горох+масличная редька и горох

\section{Влияние озимых сидератов на урожайность картофеля (2016-2018 годы)}

\begin{tabular}{|c|c|c|c|c|c|c|c|}
\hline \multirow{2}{*}{ № } & \multirow{2}{*}{ Вариант } & \multicolumn{4}{|c|}{ Урожайность по годам, т/га } & \multicolumn{2}{|c|}{ К контролю } \\
\hline & & 2016 & 2017 & 2018 & средняя & т/га & $\%$ \\
\hline \multicolumn{8}{|c|}{ Сорт Сантэ } \\
\hline 1 & $\begin{array}{l}\text { Зяблевая вспашка } \\
\text { (контроль) }\end{array}$ & 21,0 & 22,5 & 22,0 & 21,8 & - & 100 \\
\hline 2 & Весенняя вспашка & 19,0 & 20,4 & 20,0 & 19,8 & $-2,0$ & 90,8 \\
\hline 3 & Рапс & 27,4 & 28,3 & 27,8 & 27,8 & 6,0 & 127,5 \\
\hline 4 & Масличная редька & 26,0 & 27,1 & 26,8 & 26,6 & 4,8 & 122,0 \\
\hline 5 & Ячмень & 23,9 & 25,0 & 24,6 & 24,5 & 2,7 & 112,4 \\
\hline 6 & Горох & 31,4 & 32,6 & 32,1 & 32,0 & 10,2 & 146,8 \\
\hline 7 & Горчица сизая & 28,6 & 30,0 & 29,6 & 29,4 & 7,6 & 134,9 \\
\hline 8 & $\begin{array}{l}\text { Горох+масличная } \\
\text { редька }\end{array}$ & 31,1 & 31,7 & 31,4 & 31,4 & 9,6 & 144,0 \\
\hline \multicolumn{2}{|c|}{$\mathrm{HCP}_{05}$} & 1,2 & 0,9 & 1,2 & - & - & - \\
\hline \multicolumn{8}{|c|}{ Сорт Кондор } \\
\hline 1 & $\begin{array}{l}\text { Зяблевая вспашка } \\
\text { (контроль) }\end{array}$ & 24,0 & 23,5 & 22,2 & 23,2 & - & 100 \\
\hline 2 & Весенняя вспашка & 21,5 & 21,1 & 20,7 & 21,1 & $-2,1$ & 90,9 \\
\hline 3 & Рапс & 28,0 & 29,4 & 28,8 & 28,7 & 5,5 & 123,7 \\
\hline 4 & Масличная редька & 27,5 & 28,8 & 28,6 & 28,3 & 5,1 & 122,0 \\
\hline 5 & Ячмень & 26,9 & 27,6 & 27,4 & 27,3 & 4,1 & 117,7 \\
\hline 6 & Горох & 35,1 & 35,8 & 35,6 & 35,5 & 12,3 & 153,0 \\
\hline 7 & Горчица сизая & 30,1 & 31,6 & 31,0 & 30,9 & 7,7 & 133,2 \\
\hline 8 & $\begin{array}{l}\text { Горох+масличная } \\
\text { редька }\end{array}$ & 31,1 & 32,3 & 31,8 & 31,7 & 8,5 & 136,6 \\
\hline \multicolumn{2}{|c|}{$\mathrm{HCP}_{05}$} & 1,3 & 1,1 & 1,4 & - & - & - \\
\hline
\end{tabular}




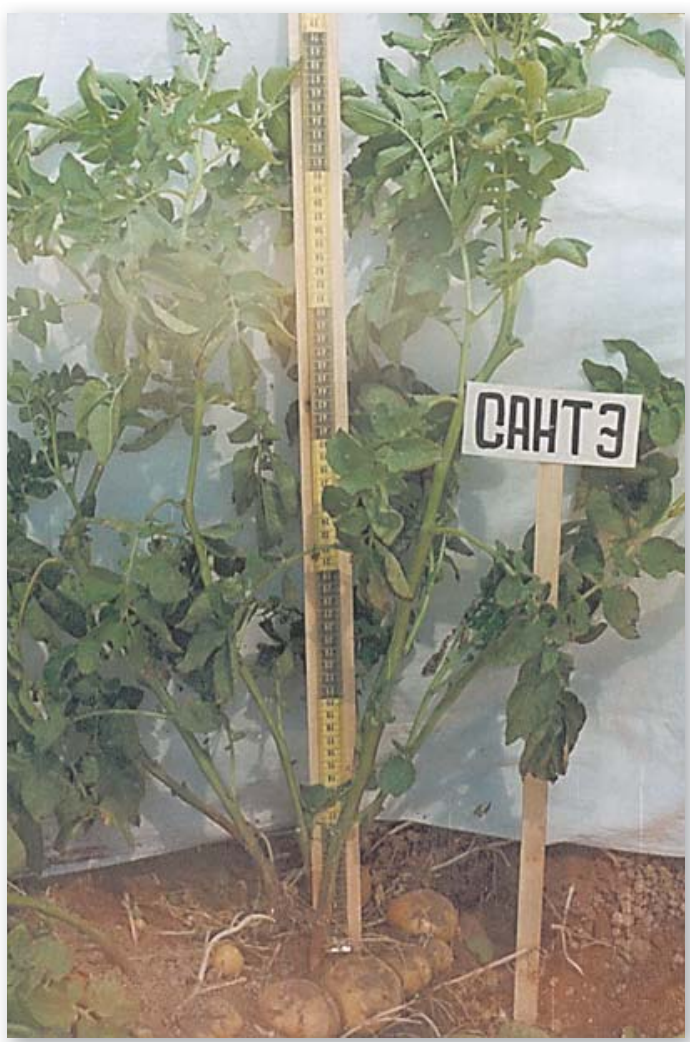

Рис. 1. Сорт картофеля Sante в период клубнеобразования

и составила 1,21-1,26 г/см³. У озимых сидератов до первого полива картофеля объемная масса почвы (0-

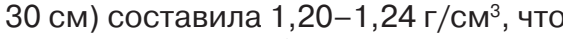

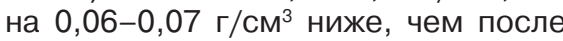
гороха и горчицы сизой. После всех поливов несущественное повышение объемной массы почвы наблюдалось после смеси горох+масличная редька.

При летних и озимых сроках применение в качестве сидератов гороха и смеси горох+масличная редька обеспечило наибольшее содержание гумуса (1,13-1,16\%). При совмещенном посеве сидератов соотношение C:N было благоприятным и в итоге усиливало гумификацию биомассы растений.

При озимых и летних сроках использования в качестве сидерата гороха и смеси горох+масличная редька отмечено наибольшее содержание нитратного азота- $\mathrm{N}-\mathrm{NO}_{3}(13,8-$ 23,56 мг/кг). А самое высокое накопление подвижного фосфора в почве (35,4-38,4 мг/кг) в летних и озимых сроках отмечали после посева рапса и смеси горох+масличная редька. Содержание подвижного фосфора существенно изменялось после озимых сидератов. С повышением содержания нитратного азота $\left(\mathrm{N}-\mathrm{NO}_{3}\right)$ под влиянием сидератов повышается и содержание подвижного фосфора. Наиболее высокое содержание обменного калия (312,5-319,6 мг/кг) было получено после сидератов рапса и горох+масличная редька.

Осенние и летние сидераты существенно влияют на полевую всхожесть семенных клубней, интенсивность появления всходов, рост и развитие растений, продолжительность вегетационного периода изученных сортов картофеля. После применения лучших сидератов - гороха и смеси горох+масличная редька полевая всхожесть семенных клубней составила по сортам 99,699,9\%, появление всходов ускорялось на 2-6 дней, а вегетационный период увеличивался на 4-8 дней, площадь листовой поверхности была на 20,6-21,7 тыс. м $^{2}$ больше, урожай клубней с одного растения было на 206,0-223,7 г больше, чем в контроле.

Урожайность изученных сортов картофеля при применении летних сидератов была на 5,0-46,7\% выше контроля. Наибольшая прибавка урожая (8,1-9,8 т/га или 36,7$46,7 \%)$ у сортов картофеля получена после использования в качестве сидерата гороха. А после использования смеси горох+масличная редька прибавка урожая по сортам составила 29,4-39,0\%.

Подобная закономерность наблюдалась и у среднеранних сортов картофеля Сантэ и Кондор после озимых сидератов. Самая высокая урожайность по сортам (32,0-35,5 т/га) или прибавка урожая 10,2-12,3 т/га была получена после использования в качестве сидерата гороха (табл.).

Относительно Высокая урожайность $(29,4-31,7$ т/ га) у сортов картофеля отмечена после использования в качестве сидератов смеси горох+масличная редька или горчицы сизой.

При использовании летних сидеральных культур урожай товарных клубней сорта Сантэ (рис. 1) был на 1,8-9,7 т/га, урожай семенных клубней на 2,6-9,4 т/га, коэффициент размножения на 0,8-2,8 выше, а доля нестандартных клубней на 1,7-2,7\% ниже по сравнению с контролем.

Такая же закономерность отмечалась у других изученных сортов картофеля - Кондор, Кувонч-1656м и Бахро-30 (рис. 2).

Самый высокий урожай товарных (30,0-31,8 т/га) и семенных клубней (21,5-23,0 т/га), а также коэффициент размножения $(6,5-7,0)$ был получен после летнего сидерата - гороха.

При использовании озимых сидеральных культур и гороха эти показатели были еще выше и по сортам составляли $31,2-35,0 ; 22,4-25,4$ и 6,77,7 соответственно.

При посадке семенных клубней картофеля, выращенных на фоне летних сидератов, полевая всхожесть на двадцатый день после посадки по сортам составила 94,797,5 что на 3,4-5,5\% выше контроля, всходы появились на 3-6 дней раньше, вегетационный период удлинялся на 3-8 дней, высота растения на 6,1-15,3 см выше, число стеблей с куста на 0,4-1,9 шт. больше, зараженность растений вирусами снижалась на 7,4-10,2\% (в явной форме), а в латентной форме на 18,2-23,4\%.

При посадке семенных клубней, выращенных на фоне гороха в качес-

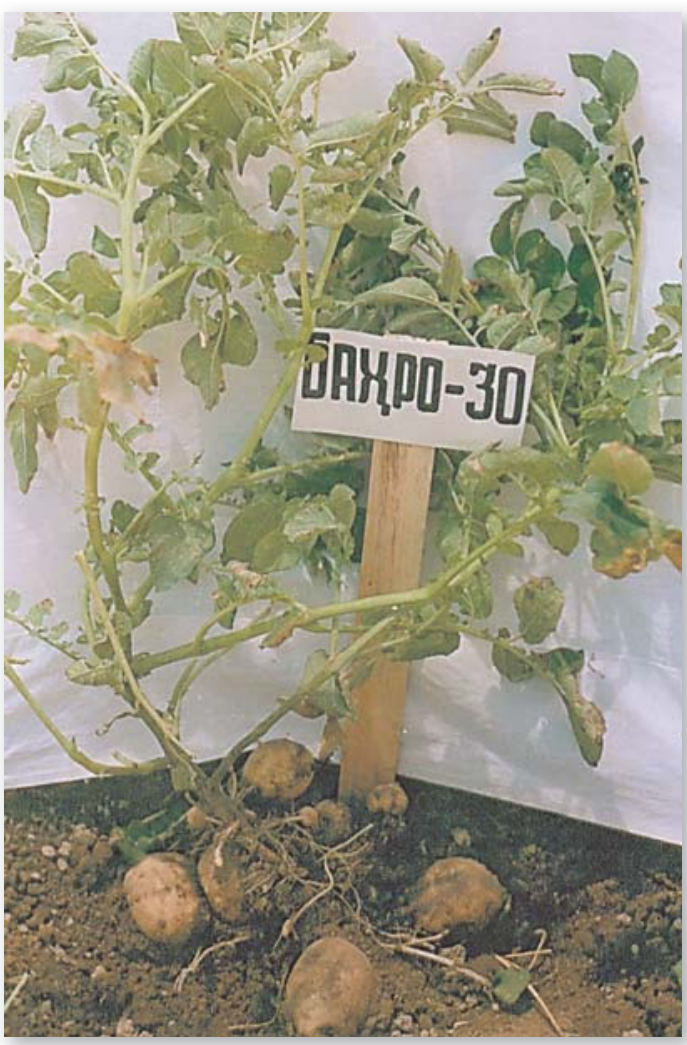

Рис. 2. Сорт картофеля Бахро-30 в период клубнеобразования 
тве летнего сидерата урожайность с 1 га по сортам составила 23,8-24,6 т, из них 22,6-23,6 т товарный урожай, доля нестандартных клубней была на 3,0-3,2\% ниже по сравнению с контролем.

Подобные результаты исследований были получены и на фоне гороха в качестве озимой сидеральной культуры. При этом выявлено, что самая высокая товарная урожайность по сортам составила 23,425,6 т/га или на 6,5-7,5 т/га больше, а доля нестандартных клубней уменьшилась на 3,1-3,4\% по сравнению с контролем.

\section{Выводы}

Применение биомассы летних и озимых сидератов в качестве зеленого удобрения способствует оптимизации гранулометрического состав, агрофизических, вод-

\section{Библиографический список}

1.Горелов Е.П., Орипов Р.О. Сидераты в борьбе с засоренностью полей // Сельское хозяйство Узбекистана. 1972. № 8. С. 15-17.

2.Орипов Р.О. Фитосанитарное и биоэнергетическое значение промежуточных культур. Ташкент, 1988. 50 с.

3.Эрназаров И.И. Промежуточные культуры в хлопководстве. Ташкент: Мехнат. 1988. 82 c.

4.Холиков Б.М. Повторные культуры и плодородие почвы. // Ўзбекистон қишлоқ хўжалиги. 2004. № 5. С. 42.

5.Бердников А.М., Косьянчук В.P. Возделывание картофеля с использованием сидератов // Земледелие. 1999. № 4. С. 26.

6.Свист В.Н., Марухленко А.В. При запашке сидератов урожай и качество картофеля повышаются // Картофель и овощи. 2010. № 4. С. 16-17.

7.Гришин С.А., Брысозовский И.И. Совместное внесение сидератов и минеральных удобрений повышает доходность отрасли // Картофель и овощи. 2010. № 1. С. 6-7.

8.Терехов И.В. Сидераты эффективны // Картофель и овощи. 2015. № 7. С. 33-34.

9.Методика исследований по культуре картофеля. М.: ВНИИКХ, 1967. 204 с.

10.Доспехов Б.А. Методика полевого опыта. М.: Агропромиздат, 1985, 351 с

\section{Об авторах}

Остонакулов Тоштемир Эшимович, доктор с.-х. наук, профессор, ректор Самаркандского с.-х. института, академик Петровской академии наук и искусств. E-mail: t-ostonakulov@mail.ru

Усмонов Носир Нурманович, канд. с.-х. наук, докторант Самаркандского Института ветеринарной медицины ных свойств почвы и микробиологических процессов в пахотном слое. Наибольший эффект в наших исследований был при использовании в качестве сидеральных культур гороха, рапса и смеси горох+масличная редька.

При использовании этих сидератов отмечены наибольшая урожайность товарных клубней $(30,3-35,0$ т/га), семенных клубней (21,2-25,4 т/га), урожайность и коэффициент размножения $(6,4-7,7)$ у изученных сортов картофеля. При этом доля нестандартных клубней не превышала 2,3-2,9\%. Зараженность растений вирусами снизилась на 10,7-11,1\% (в явной форме), на 23,8-24,5\% (в латентной форме) по сравнению с контролем.

\section{References}

1.Gorelov E.P, Oripov R.O. Siderate crops in the fight against weed fields. Agriculture of Uzbekistan. 1972. No8. Pp. 15-17. (In Russ.).

2.Oripov R.O. Phytosanitary and bioenergetic value of intermediate crops. Tashkent: 1988.50 p. (In Russ.).

3.Ernazarov I.I. Intermediate crops in cotton growing. Tashkent: Mehnat. 1988. 82 p. (In Uzb.).

4.Kholikov B.M. Repeated crops and soil fertility. Agriculture of Uzbekistan. Tashkent. 2004. No5. P. 42. (In Uzb.).

5.Berdnikov A.M., Kosyanchuk V.R. Cultivation of potatoes using siderates. Agriculture. 1999. No4. P. 26. (In Russ.).

6.Swist V.N., Marukhlenko A.V. Potato yield and quality increase at plowing siderates. Potatoes and vegetables. 2010. No4. Pp. 16-17. (In Russ.).

7.Grishin S.A., Brysozovsky I.I. The combined application of siderates and mineral fertilizers increases the profitability of the industry. Potatoes and vegetables. 2010. No1. Pp. 6-7. (In Russ.).

8.Terekhov I.V. Siderates are effective. Potatoes and vegetables. 2015. No7. Pp. 33-34. (In Russ.).

9. Methods of research on potato crop. Moscow. VNIIKH. 1967. 204 p. (In Russ.)

10.Dospekhov B.A. Methodology of field experience. Moscow. Agropromizdat. 1985. 351 p. (In Russ.).

\section{Author details}

Ostonakulov T.E., Doctor Sci (Agr.), professor, rector of Samarkand Agricultural Institute, academician of the Peter the Great Academy of Sciences and Arts. E-mail: t-ostonakulov@mail.ru

Usmonov N.N., Cand. Sci (Agr.), doctoral student at the Samarkand Institute of Veterinary Medicine

\section{Успехи курских картофелеводов}

Курская область полностью обеспечена картофелем собственного производства

Как сообщили в Комитете АПК Курской области, на потребительском рынке региона сохраняется стабильная ситуация с обеспечением населения социально значимыми продовольственными товарами. Насыщенность торговых сетей области картофелем и овощами сформирована в основном за счет собственного производства этой продукции. В прошлом году в хозяйствах всех категорий Курской области произведено 465,5 тыс. т картофеля. Это позволило полностью обеспечить потребности населения в данной продукции.

Производством картофеля в регионе помимо личных подсобных хозяйств занимается 22 с.- х. товаропроизводителя. Самая большая картофельная плантация (1050 га) расположена в ООО «Толпино» Кореневского района. В 2019 году здесь собрали более 45 тыс. т картофеля.

Семенами картофеля, минеральными удобрениями, необходимыми ресурсами хозяйства региона, занимающиеся картофелеводством, обеспечены. В текущем году в регионе планируется увеличить площади под картофелем до 1880 га. В планах картофелеводческих хозяйств и ЛПХ региона произвести в 2020 году около 500 тыс. т картофеля.

На особом контроле в регионе ситуация с обеспечением хранения овощей и картофеля. В настоящий момент в Курской области имеется 7 картофелехранилищ общей мощностью 85,2 тыс. т, 4 овощехранилища на 3,4 тыс. т, 7 плодохранилищ, рассчитанных на 12,8 тыс. т. В 2021 году планируется ввести в эксплуатацию дополнительно плодохранилище ООО «Зоринский сад» Обоянского района на 5 тыс. т.

Источник: www.adm.rkursk.ru

В №4 журнала за 2020 год на с. 12 в средней колонке в первом абзаце сверху напечатано: 2. $N_{120} P_{60} K_{180}$ (расчетная доза на 50 т/га).

Следует читать: 2. $N_{120} P_{60} K_{180}$ (расчетная доза на 50 т/га урожая свеклы). 